\title{
Antibacterial Efficacy of a Dispersion of Silver Nanoparticles in Citrate Medium for the Treatment of E. faecalis: In Vitro Study
}

\section{Eficacia antibacterial de una dispersion de nanopartículas de plata en medio de citrato para la eliminación de E. faecalis: Estudio In Vitro}

\author{
Silvia Rodríguez-Chang DDS1; Tatiana Ramírez-Mora DDS, MSc²; \\ Grettel Valle-Bourrouet PhD3; Norman Rojas-Campos MSc ; \\ Daniel Chavarría-Bolaños DDS, MSc, PhD²; Mauricio Montero-Aguilar DDS, MSc²
}

1. Caja Costarricense del Seguro Social, Costa Rica. Resident, Advanced General Dentistry Graduate Program, University of Costa Rica, Costa Rica.

2. School of Dentistry, University of Costa Rica, Costa Rica.

3. School of Chemistry, University of Costa Rica, Costa Rica.

4. School of Microbiology, University of Costa Rica, Costa Rica.

Correspondence to: Dr. Mauricio Montero Aguilar - mauricio.monteroaguilar@ucr.ac.cr

Received: 29-|II-2016

Accepted: 21-IV-2016

Published Online First: 26-IV-2016

DOI: http://dx.doi.org/10.15517/ijds.v0i0.23929

ABSTRACT

The purpose of this study was to measure the antibacterial efficacy of a dispersion of silver nanoparticles (AgNP) in a citrate medium tested in two E. faecalis strains. AgNP were synthesized, and AgNP citrate medium (AgNP-CM) dispersion was prepared at a concentration of $100 \mu \mathrm{g} / \mathrm{mL}$. The antibacterial efficacy of AgNP-CM dispersion was evaluated over two E. faecalis strains: ATCC29212 and a wild strain collected from human necrotic teeth. $5 \%$ sodium hypochlorite $(\mathrm{NaOCl})$ and sterile saline solution were used as positive and negative controls. 5 and 30-minute contact tests were conducted and each experimental group were replicated 10 times. After 24 hours of incubation, the Log CFU/ $\mathrm{mL}$ were calculated. The AgNP obtained showed spherical shapes and had 30-60nm size. 5\% $\mathrm{NaOCl}$ was able to completely eliminate both $E$. faecalis strains in all groups, showing a significant statistical difference when compared to AgNP-CM dispersion and negative control groups. AgNP-CM dispersion showed a statistically significant decrease in Log CFU/mL averages $(p=0,0006)$ when compared to the sterile saline solution for the ATCC29212 strain during the 30-minute time. Between the 5-minute and 30-minute groups, a significant bacterial count decrease was also observed $(p=0,0128)$. The antibacterial efficacy of the dispersion was greater for the ATCC29212 strain than the wild strain, were the effect diminished. AgNP-CM dispersion showed a significantly lower antibacterial efficacy against E. faecalis than the $5 \% \mathrm{NaOCl}$ at the tested times.

\section{KEYWORDS}

Antimicrobial efficacy; Silver nanoparticles; Sodium hypochlorite; E. faecalis.

RODRÍGUEZ S., RAMÍREZ T., VALLE G., ROJAS N., CHAVARRÍA D., MONTERO M., 2016: Antibacterial Efficacy of a Dispersion of Silver Nanoparticles in Citrate Medium for the Treatment of E. faecalis: In Vitro Study.-ODOVTOS-Int. J. Dental Sc., 18-2 (May-August): 99-107. 


\section{RESUMEN}

El propósito del presente estudio fue medir la eficacia antibacteriana de una dispersión de nanopartículas de plata (AgNP) en medio de citrato ante dos cepas de E. faecalis. Las AgNP fueron sintetizadas y se preparó una dispersión en medio de citrato (AgNP-CM) en una concentración de 100 $\mu \mathrm{g} / \mathrm{mL}$. La eficacia antibacteriana de la dispersión de AgNP-CM fue evaluada ante dos cepas de $E$. faecalis: la ATCC29212 pura y una cepa silvestre aislada de un tratamiento endodóntico fallido. Se utilizó hipoclorito de sodio al $5 \%$ de concentración ( $\mathrm{NaOCl}$ ) y solución salina estéril como controles positivos y negativos. Se realizaron pruebas de contacto durante 5 y 30 minutos y cada grupo experimental se replicó 10 veces. Después de incubar las muestras durante 24 horas, se calcularon las concentraciones Log CFU/mL. Las AgNP obtenidas mostraron formas esféricas y un tamaño entre los 30 y $60 \mathrm{~nm}$. El $\mathrm{NaOCl} 5 \%$ logró eliminar por completo las cepas bacterianas en todos los grupos, mostrando una diferencia estadísticamente significativa al compararse con las dispersiones de AgNP-CM y los controles negativos. La dispersión de AgNP-CM mostró una disminución estadísticamente significativa en los promedios Log CFU/mL al compararse con la solución salina estéril para la cepa ATCC29212 a los 30 minutos de contacto. Entre los grupos de 5 y 30 minutos de la dispersión, se observó también una disminución en el conteo bacteriano ( $p=0,0128)$. La eficacia antibacteriana de la dispersión fue mayor para la cepa ATCC29212 que para la cepa silvestre donde su efecto se vio disminuido. La dispersión de AgNP-CM mostró una significativa baja eficacia ante el E. faecalis al compararse con el $\mathrm{NaOCl} 5 \%$ a los tiempos probados.

\section{PALABRAS CLAVE}

Eficacia antimicrobiana; Nanopartículas de plata; Hipoclorito de sodio; E. faecalis.

\section{INTRODUCTION}

Enterococcus faecalis plays a role in the etiology of persistent endodontic infections (1). It has been related to up to $77 \%$ of root canal treatment failures $(2,3)$, mainly due to its different virulence factors such as adherence to host cells and extracellular matrix, increased tissue invasion, direct immunomodulation, and toxin-mediated damage (2). These bacteria can survive adverse clinical conditions, are able to create biofilms, and can penetrate deep into dentinal tubules $(4,5)$. In addition, they have the ability to resist intracanal medication, and survive in the dentinal tubule system for long periods due to its multiple genetic polymorphisms $(6,7)$.

Chemical irrigation plays an important role in the endodontic treatment (8). In combination with appropriate mechanical instrumentation, irrigation is essential for an adequate debridement and disinfection of the infected root canal (3). Sodium hypochlorite $(\mathrm{NaOCl})$ is considered the ideal irrigant solution, due to its multiple benefits such as antimicrobial spectrum (against bacteria, mycobacteria, spores, virus, algae and protozoa), its unique capacity to dissolve organic tissue because of its high $\mathrm{pH}(11,8)$ and its ability to neutralize acid environments, preventing bacterial growth $(6,11)$. Both, in vivo and in vitro studies in concentrations ranging from $2.5 \%$ to $5.25 \%$ supported these facts $(9,10)$. However, its main disadvantage consisted in its high toxicity after contacting healthy tissue (12).

Silver nanoparticles (AgNP) offers physical, chemical, optical, and biological properties different from other biomedical nanomaterials 
$(13,14)$, being an alternative as antibacterial agents with acceptable broad spectrum of activity and biocompatibility $(15,16)$. Their antibacterial activity is a result of their cationic nature and high surface density $(17,18)$, with increased interaction with bacterial cells (19). Studies analyzing AgNP antimicrobial activity have shown effectiveness against Gram-negative and Grampositive microorganisms (20); however, its main mechanism of action is not fully understood (14). They have been associated with increased adherence to bacterial cell wall, increasing membrane permeability and subsequently bacterial death $(17,21)$. AgNP enhance the release of silver ions, affecting the bacterial respiratory chain because of reactive oxygen species (ROS) and reactive nitrogen species (RNS) production $(22,23)$ which leads to cell damage and finally apoptosis (13). AgNP also affect bacterial DNA and RNA through denaturation and hamper bacterial replication process $(24,25)$.

Current investigations addressed to develop a root canal irrigant with the ability to disseminate through the root canal system, with a prolonged controlled action, capable to eliminate both aerobic and anaerobic microorganisms not only during but also after the root canal treatment, with acceptable biocompatibility at the same time. Thus, the aim of this study was to evaluate the antibacterial efficacy of an AgNP-citrate medium (AgNP-CM) dispersion against two E. faecalis.

\section{MATERIALS AND METHODS}

This in vitro study was conducted as a collaboration between the Inorganic Chemistry Laboratory of the School of Chemistry, the Medical Bacteriology Laboratory of the School of Microbiology and the Graduate School Programs of the School of Dentistry of the University of Costa Rica.

\section{SYNTHESIS OF SILVER NANOPARTICLES}

For AgNP synthesis, $17 \mathrm{mg}$ of $\mathrm{AgNO}_{3}$ (Sigma-Aldrich, MO, US) solution was combined with $100 \mathrm{~mL}$ of distilled deionized water $(18 \mathrm{mS})$, which was brought to boiling point. Then, $10 \mathrm{~mL}$ of trisodium citrate (Sigma-Aldrich, MO, US) into $1 \% \mathrm{~m} / \mathrm{v}$ deionized water was infused. The solution kept warm at $37^{\circ} \mathrm{C}$ under continuous stirring until it changed its color from a yellowish tone to a final green appearance, after a 5 minutes period. This process allowed the formation of the AgNP-CM dispersion, in a final concentration of $100 \mu \mathrm{g} / \mathrm{ml}$, as previously reported (26).

A separate sample of AgNP-CM dispersion was used for characterization purposes. Consequently, AgNP were separated through centrifugation (Eppendorf Centrifuge 5810R, Hamburg, Germany) AT $15.000 \mathrm{G}$ and under $-4^{\circ} \mathrm{C}$ in three consecutive cycles of 15 minutes each. Distilled deionized water was used for rinsing between each centrifugation; eliminating the supernatant present. The remaining precipitate was lyophilized and scattered again using distilled deionized water. $50 \mu \mathrm{L}$ of the dispersion of AgNP was placed in a copper grid and dried in a laminar flow hood. Finally, the resulting combination was evaluated by Transmission Electron Microscopy (HT7700 $120 \mathrm{kV}$, Ibraraki, Japan) to confirm the presence and dimension of AgNP.

\section{BACTERIAL STRAIN PREPARATION}

Two bacterial strains in this experiment were selected: a wild strain of E. faecalis (isolated from a failed endodontic treatment) which was identified by an automatic VITEK 2 Compact system (bioMerieux, Lyon, France) and an ATCC29212 strain of the American Type Culture Collection (ATCC, Rockville, MD, US). Both strains were maintained frozen at $-70^{\circ} \mathrm{C}$ in a brain heart 
infusion broth (BHI) with 5\% glycerol (Whitehouse Station, NJ, US). Bacterial strains were grown in blood agar for 24 hours at $37^{\circ} \mathrm{C}$. The colonies were dispersed in sterile saline solution $(\mathrm{pH} 7,2)$ to form a suspension of approximately $1.5 \times 108 \mathrm{CFU} / \mathrm{mL}$ (McFarland Standard of 0.5 ) verified by colorimetry using densiCHEK plus (bioMerieux, Lyon, France).

\section{ANTIBACTERIAL TESTS}

Groups for antibacterial tests were the experimental group (EG) evaluating $100 \mu \mathrm{g} / \mathrm{mL}$ AgNP-CM dispersion, a positive control (PC) using $5 \% \mathrm{NaOCl}$ (Laboratorios Químicos ARVI S.A., Cartago, Costa Rica), and a negative control (NC) using sterile saline solution. Ten experiments for each of the solutions in accordance with Crémieux and Fleurette method were performed (27). For this analysis, $1 \mathrm{~mL}$ of the bacterial suspension was kept in contact during 5 minutes and 30 minutes under continuous stirring at $180 \mathrm{rpm}$ with $1 \mathrm{~mL}$ of each solution (EG or the respective controls). Final combinations were diluted form $10^{-1}$ to $10^{-9}$, and $0.1 \mathrm{~mL}$ of every solution plated in blood agar duplicates for counting. After $24 \mathrm{~h}$ of incubation at $37^{\circ} \mathrm{C}$, colony-forming units (CFU) per $\mathrm{mL}$ was determined.

\section{STATISTICAL ANALYSIS}

Data were processed using MegaStat $\circledast$ statistics package for Microsoft $\circledast$ Excel. The means, standard deviations, and relative increase (RI) of the CFU logarithm per millimeter (log CFU/ $\mathrm{mL}$ ) were calculated. A Student's t-test considering a significance level of 0.05 was applied.

\section{RESULTS}

Analysis of AgNP by TEM at 20000x showed ball-shaped structures, sized between 30 and 60 nm (Figure 1).

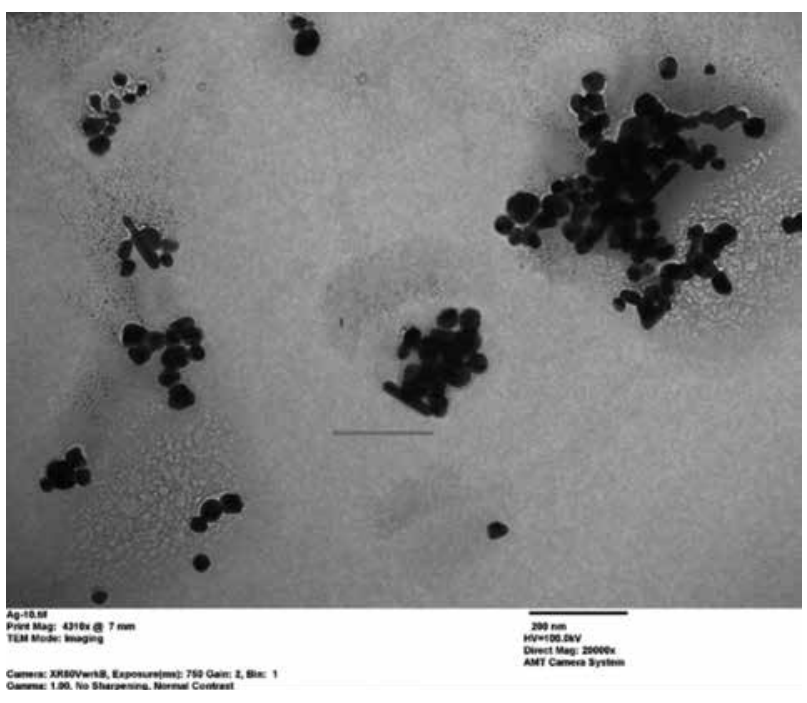

Figure 1. Analysis of AgNP by TEM at 20000x.

Figure 2 shows the results of the antibacterial effect by comparing CFU logarithm average per millimeter ( $\mathrm{Log} \mathrm{CFU} / \mathrm{mL}$ ) of the AgNP-CM dispersion and controls over against E. faecalis ATCC29212 strain. $5 \% \mathrm{NaOCl}$ was able to eliminate completely all bacteria after 5 min of contact. At the same period, no significant difference was observed between the inhibition of AgNP-CM dispersion and saline solution $(p=0,6819)$. Nevertheless, when comparing these two solutions after 30 min of contact, AgNP-CM dispersion showed a significant statistical decrease in the bacterial growth $(p=0,0006)$.

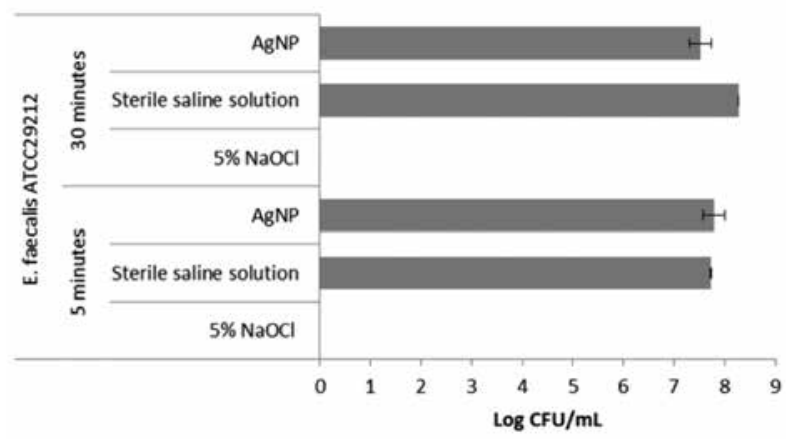

Figure 2. $\mathrm{CFU} / \mathrm{mL}$ logarithm average and standard deviation comparison by time between solutions for E. faecalis ATCC29212 $(\mathrm{N}=10)$. 
Figure 3 shows the results of Log CFU/ $\mathrm{mL}$ averages of AgNP, compared with $5 \% \mathrm{NaOCl}$ and sterile saline solution for the wild E. faecalis strain after 5 and $30 \mathrm{~min} .5 \% \mathrm{NaOCl}$ eliminated all bacteria after 5 minutes of contact. AgNPCM dispersion showed averages not statistically different results from the saline solution group after $5(p=0.086)$ and 30 min contact $(p=0.4683)$.

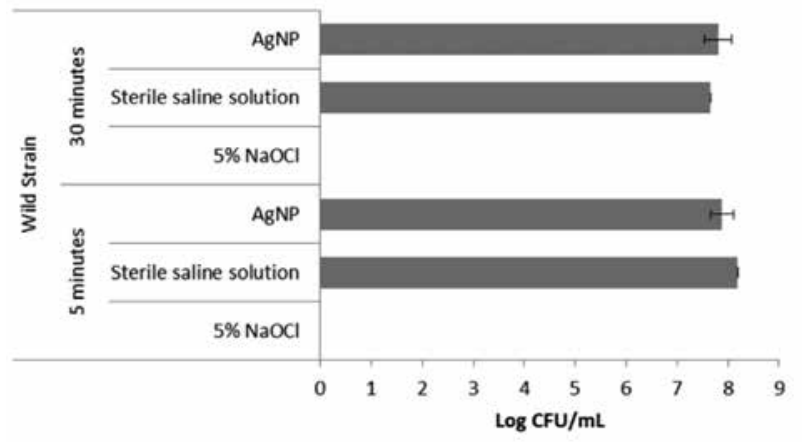

Figure 3. Log CFU/mL average and standard deviation comparison by time between solutions for wild $\mathrm{E}$. faecalis strain $(\mathrm{N}=10)$.

When comparing the antibacterial efficacy for AgNP-CM dispersion by time for each $E$. faecalis strain, a significant decrease in bacterial growth of E. faecalis ATCC29212 from minute 5 to minute 30 ( $p=0,0128$ ) was found (Figure 4). This result represents a relative increase of $-9 \%$. In the case of the wild strain, no significant statistical difference was found when comparing both time groups ( $p=0.5146$ and $B=0,6648)$.

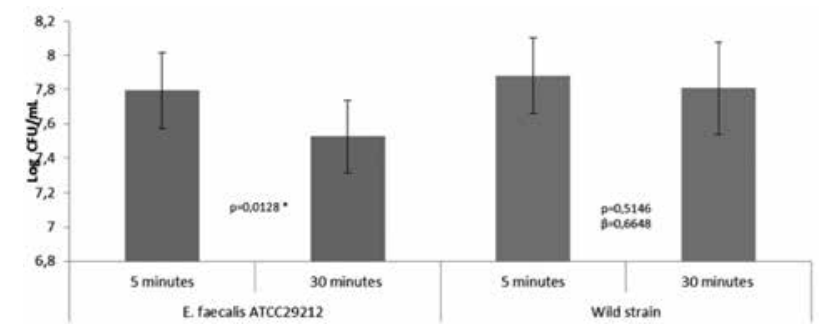

Figure 4. Average antibacterial efficacy of AgNP in a $100 \mu \mathrm{g} / \mathrm{mL}$ citrate medium by strain by time ( ${ }^{*}$ significant difference).

\section{DISCUSSION}

This study determined the antimicrobial in vitro efficacy of a dispersion of silver nanoparticles in a $100 \mu \mathrm{g} / \mathrm{mL}$ citrate medium for the treatment of E. faecalis ATCC29212 and a wild strain using the contact test. Our investigation determined that obtaining silver nanoparticles using a citrate medium as reducing agent was possible, achieving desirable spherical structures with sizes under the $100 \mathrm{~nm}$. The direct contact method for antibacterial tests selected is a quantitative and reproducible method widely used to assess antimicrobial effects in irrigants, sealants and root canal filling materials (28).

A dispersion of nanoparticles as an alternative endodontic irrigant due to its bactericidal potential and biocompatibility, especially in low concentrations has been recommended $(15,29)$. Accordingly, nanoparticles sized over $10 \mathrm{~nm}$ have not been associated with cytotoxic effects (30). Previous studies suggested that zinc oxide nanoparticles sized between 60-100 nm and chitosan are useful as intracanal medication with a desirable antibacterial activity against $E$. faecalis (31). In a similar way, 3.8\% silver diamine fluoride shows an antibacterial efficacy similar to $5.25 \%$ $\mathrm{NaOCl}$ in similar exposure times in the treatment of E. faecalis; therefore, it was proposed as an irrigant or intracanal medication due to silver ions release; capable to penetrate as far as $40 \mu \mathrm{m}$ into dentinal tubules, with long-lasting antimicrobial effect (32). There are reports of antibacterial properties of these nanoparticles up to 90 days after being applied (33). In addition, a suspension of AgNP at a concentration of $100 \mu \mathrm{g} / \mathrm{mL}$ favors the transportation of calcium hydroxide inside the root canal increasing its effectiveness against E. faecalis biofilm (5). The combination between 
calcium hydroxide and $200 \mu \mathrm{g} / \mathrm{mL}$ AgNP (sized in $70 \mathrm{~nm}$ ) was also effective eliminating $E$. faecalis after only 1 day of contact (34).

Our study compared the antibacterial efficacy of $100 \mu \mathrm{g} / \mathrm{mL}$ AgNP with $5 \% \mathrm{NaOCl}$ in 5 -min and $30-$ min times. The $5 \% \mathrm{NaOCl}$ groups inhibit both $E$. faecalis strains in all contact times, showing a significant statistical difference when compared to AgNP-CM and the negative control. This result verifies the $\mathrm{NaOCl}$ capability to eliminate E. faecalis bacteria and demonstrates that AgNP are not highly efficient as a direct irrigant.

When the antibacterial efficiency of AgNPCM with a sterile saline solution for $E$. faecalis ATCC 29212 compared, no bacterial growth decrease occurred during the 5-minute contact. However, during the 30-minute contact, a significant decrease in $\mathrm{Log} \mathrm{CFU} / \mathrm{mL}$ average occurred. Furthermore, bacterial count decreased when comparing 5-minute and 30-minute times. These results are consistent with the conclusions of previous studies, which suggested bacterial rate of destruction caused by nanoparticles depended on the concentration and the interaction time $(14,31)$. In other studies, the interaction time was 72 hours, leading to the complete destruction of $E$. faecalis (35). Recently, AgNP showed higher antibacterial efficacy than gold nanoparticles and zinc nitrate added to toothpastes for destroying $E$. faecalis (36). AgNP as an irrigant in a concentration of 10 $\mu \mathrm{g} / \mathrm{mL}$ during 2-minute contact did not decrease the number of bacteria in an $E$. faecalis biofilm. However, when used as intracanal medication in a concentration of $2 \mu \mathrm{g} / \mathrm{mL}$ during 7 days, the bacterial count decreased (37).

Similar studies recommended the use of isolated wild native strains for antibacterial efficacy studies in order to compare their behavior with standard ATCC29212 strain, which is the most studied species (28). Regarding the results of comparing Log CFU/mL averages of AgNP-CM and sterile saline solution, the wild strain showed a relative increase during the 5-minute contact; nonetheless, there was no significant statistical difference for the 5-minute or the 30-minute contact. In a study of quaternary ammonium polyethylenimine (QPEI) nanoparticles added to two luting cements, the antibacterial effect only after 60-minute contact with E. faecalis RW35, whereas in the ATCC29212 strain, the effect was evident only after 10-minute contact (28). In our study, the antibacterial efficacy of AgNP nanoparticles for the treatment of a wild strain of $E$. faecalis was lower when compared to the ATCC29212 strain. The AgNP-CM effect in both strains demonstrate that there is significant difference during the 30 min contact, where the antibacterial efficacy was greater in the ATCC29212 strain. After 5-minute contact, there was no significant difference since both strains have a similar behavior. However, it is not possible to correlate both results due to type II error range. Since no bactericidal effect was observed after 5 and 30 min contact, further studies are suggested in order to evaluate prolonged contact periods, as well as the specific mechanisms involving AgNP over E. faecalis. Also, future studies should analyze how to increment their effectiveness in short-term periods to be used as direct antimicrobial agents; such as an endodontic irrigant.

\section{CONCLUSION}

The antibacterial efficacy of AgNP-CM is directly proportional to the time of application and was more effective against the ATCC29212 strain than to the wild strain. AgNP-CM does not seem to be effective in eliminating $E$. faecalis when compared to $5 \% \mathrm{NaOCl}$. 


\section{REFERENCES}

1. Zhang C., Du J., Peng Z. Correlation between Enterococcus faecalis and Persistent Intraradicular Infection Compared with Primary Intraradicular Infection: A Systematic Review. J Endod. 2015; 41(8): 1207-13.

2. Portenier I., Waltimo T. M. Haapasalo M. Enterococcus faecalis- the root canal survivor and 'star' in post-treatment disease. Endod Topics. 2003; 6 (1): 135-59.

3. Luddin N., Ahmed H. The antibacterial activity of sodium hypochlorite and chlorhexidine against Enterococcus faecalis: A review on agar diffusion and direct contact methods. J. Conserv Dent. 2013;16: 9-16.

4. Kayaoglu G., Ørstavik D. Virulence Factor of Enteroccus Faecalis: Relationship to Endodontic. Crit Rev Oral Biol Med. 2004; 15 (5): 308-20.

5. Afkhami F., Pourhashemi S. J., Sadegh M., Salehi Y., Fard MJK. Antibiofilm efficacy of silver nanoparticles as a vehicle for calcium hydroxide medicament against Enterococcus faecalis. J. Dent. 2015; 43 (12): 1573-9.

6. Karale R., Thakore A., Shetty V. An evaluation of antibacterial efficacy of $3 \%$ sodium hypochlorite, high-frequency alternating current and $2 \%$ chlorhexidine on Enterococcus faecalis: An in vitro study. J. Conserv Dent. 2011;14 (1): 2-5.

7. Gandi P., Vasireddi S. R., Gurram S. R., Darasani K. Evaluation of the Antibacterial efficacy of Omeprazole with Sodium Hypochlorite as an Endodontic Irrigating Solution- An Invivo Study. J. Int. Oral Health. 2013; 5 (2): 14-20.

8. Davis J. M., Maki J., Bahcall J. K. An in vitro comparison of the antimicrobial effects of various endodontic medicaments on Enterococcus faecalis. J. Endod. 2007; 33 (5): 567-9.
9. Hidalgo E., Bartolome R., Dominguez C. Cytotoxicity mechanisms of sodium hypochlorite in cultured human dermal fibroblasts and its bactericidal effectiveness. Chem Biol Interact. 2002; 139 (3): 265-82.

10. Haapasalo H. K., Siren E. K., Waltimo T. M., Orstavik D., Haapasalo M. P. Inactivation of local root canal medicaments by dentine: an in vitro study. Int. Endod J. 2000; 33 (2): 126-31.

11. Shenoy A., Mandava P., Bolla N., Raj S., Kurien J., Prathap M. S. Antibacterial efficacy of sodium hypochlorite with a novel sonic agitation device. Indian J. Dent Res. 2013; 24 (5): 537-41.

12. Zehnder M. Root canal irrigants. J. Endod. 2006; 32 (5): 389-98.

13. Wei L., Lu J., Xu H., Patel A., Chen Z. S., Chen G. Silver nanoparticles: synthesis, properties, and therapeutic applications. Drug Discov Today. 2015; 20 (5): 595-601.

14. Correa J. M., Mori M., Sanches H. L., da Cruz A. D., Poiate E., Jr., Poiate I. A. Silver nanoparticles in dental biomaterials. Int. J. Biomater. 2015; 2015: 485275.

15. Gomes-Filho J. E., Silva F. O., Watanabe S., Cintra L. T., Tendoro K. V., Dalto L. G. et al. Tissue reaction to silver nanoparticles dispersion as an alternative irrigating solution. J. Endod. 2010; 36 (10): 1698-702.

16. Ge L., Li Q., Wang M., Ouyang J., Li X., Xing M. M. Nanosilver particles in medical applications: synthesis, performance, and toxicity. Int J. Nanomedicine. 2014; 9: 2399-407.

17. García-Contreras R., Argueta-Figueroa L., Mejía-Rubalcava C., Jiménez-Martínez R., Cuevas-Guajardo S., Sánchez-Reyna P. A., et al. Perspectives for the use of silver nanoparticles in dental practice. Int. Dent J. 2011; 61 (6): 297-301.

18. dos Santos C. A., Seckler M. M., Ingle A. P., Gupta I., Galdiero S., Galdiero M., et al. Silver nanoparticles: therapeutical uses, 
toxicity, and safety issues. J. Pharm Sci. 2014; 103 (7): 1931.

19. Wei L., Tang J., Zhang Z., Chen Y., Zhou $\mathrm{G}$., $\mathrm{Xi} \mathrm{T}$. Investigation of the cytotoxicity mechanism of silver nanoparticles in vitro. Biomed Mater. 2010; 5 (4): 044103.

20. Flores C. Y., Minan A. G., Grillo C. A., Salvarezza R. C., Vericat C., Schilardi P. L. Citrate-capped silver nanoparticles showing good bactericidal effect against both planktonic and sessile bacteria and a low cytotoxicity to osteoblastic cells. ACS Appl Mater Interfaces. 2013; 5 (8): 3149-59.

21. Rai M., Yadav A., Gade A. Silver nanoparticles as a new generation of antimicrobials. Biotech Adv. 2009; 27 (1): 76-83.

22. Bressan E., Ferroni L., Gardin C., Rigo C., Stocchero M., Vindigni V., et al. Silver nanoparticles and mitochondrial interaction. Int J Dent. 2013; 2013: 312747.

23. Gaillet S., Rouanet J. M. Silver nanoparticles: their potential toxic effects after oral exposure and underlying mechanisms--a review. Food Chem Toxicol. 2015; 77: 58-63.

24. FranciG., FalangaA., Galdiero S., PalombaL., Rai M., Morelli G., et al. Silver nanoparticles as potential antibacterial agents. Molecules. 2015; 20 (5): 8856-74.

25. Markowska K., Grudniak A. M., Wolska K. I. Silver nanoparticles as an alternative strategy against bacterial biofilms. Acta Biochim Pol. 2013; 60 (4): 523-30.

26. Singh R. P., Ramarao P. Cellular uptake, intracellular trafficking and cytotoxicity of silver nanoparticles. Toxicol Lett. 2012; 213 (2): 249-59.

27. Sassone L. M., Fidel R. A., Fidel S. R., Dias M., Hirata R. J. Antimicrobial activity of different concentrations of $\mathrm{NaOCl}$ and chlorhexidine using a contact test. Braz Dent J. 2003;14(2):99-102.
28. Barros J., Silva M. G., Rodrigues M.A., Alves F. R., Lopes M. A., Pina-Vaz I., et al. Antibacterial, physicochemical and mechanical properties of endodontic sealers containing quaternary ammonium polyethylenimine nanoparticles. Int Endod J. 2014; 47 (8): 725-34.

29. Samiei M., Farjami A., Dizaj S. M., Lotfipour F. Nanoparticles for antimicrobial purposes in Endodontics: A systematic review of in vitro studies. Mater Sci Eng C Mater Biol Appl. 2016; 58: 1269-78.

30. Manikandan R., Manikandan B., Raman T., Arunagirinathan K., Prabhu N. M., Jothi Basu M., et al. Biosynthesis of silver nanoparticles using ethanolic petals extract of Rosa indica and characterization of its antibacterial, anticancer and anti-inflammatory activities. Spectrochim Acta A Mol Biomol Spectrosc. 2015; 138: 120-9.

31. Kishen A., Shi Z., Shrestha A., Neoh K. An Investigation on the Antibacterial and Antibiofilm Efficacy of Cationic Nanoparticulates for Root Canal Disinfection. J. Endod. 2008; 34 (12): 1515-20.

32. Hiraishi N., Yiu C. K., King N. M., Tagami J., Tay F. R. Antimicrobial efficacy of 3.8\% silver diamine fluoride and its effect on root dentin. J Endod. 2010; 36 (6): 1026-9.

33. Shrestha A., Shi Z., Neoh K. G., Kishen A. Nanoparticulates for antibiofilm treatment and effect of aging on its antibacterial activity. J Endod. 2010; 36 (6): 1030-5.

34. Javidi M., Afkhami F., Zarei M., Ghazvini K., Rajabi O. Efficacy of a combined nanoparticulate/calcium hydroxide root canal medication on elimination of Enterococcus faecalis. Aust Endod J. 2014; 40(2): 61-5.

35. Shrestha A., Zhilong S., Gee N., Kishen A. Nanoparticulates for Antibiofilm Treatment and Effect of Aging on Its Antibacterial Activity. J Endod. 2010; 36 (6): 1030-5. 
36. Junevicius J., Zilinskas J., Cesaitis K., 37. Wu D., Fan W., Kishen A., Gutmann J. L., Cesaitiene G., Gleiznys D., Mazeliene Z. Fan B. Evaluation of the antibacterial efficacy Antimicrobial activity of silver and gold in toothpaste: A comparative analysis. Stomatologija. 2015; 17: 9-12. of silver nanoparticles against Enterococcus faecalis biofilm. J. Endod. 2014; 40 (2): 285-90. 